\title{
THE EFFECTS OF TWO FITNESS PROGRAMS WITH DIFFERENT METABOLIC DEMANDS ON OXIDATIVE STRESS IN THE BLOOD OF YOUNG FEMALES
}

Dusica Djordjevic ${ }^{1}$, Jelica Stojanovic Tosic ${ }^{1}$, Djordje Stefanovic ${ }^{1}$, Nevena Barudzic ${ }^{1}$, Milena Vuletic ${ }^{1}$, Vladimir Zivkovic ${ }^{1}$, Vladimir Jakovljevic ${ }^{1}$ ${ }^{1}$ Department of Physiology, Faculty of Medical Sciences, University of Kragujevac, Kragujevac, Serbia

\section{EFEKTI DVA FITNES PROGRAMA SA RAZLIČITIM METABOLIČKIM ZAHTEVIMA NA OKSIDATIVNI STRES U KRVI MLADIH DEVOJAKA

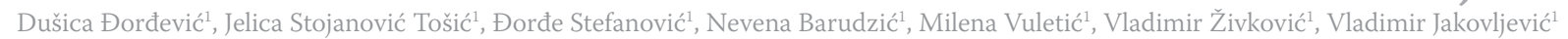 ${ }^{1}$ Katedra za fiziologiju, Fakultet medicinskih nauka, Univerzitet u Kragujevcu, Kragujevac, Srbija}

\section{ABSTRACT}

The aim of the present study was to assess the effects of two metabolically different exercise programs on the redox state of women who were physically inactive before the beginning of the study. For this purpose, participants (women $25 \pm 5$ years old) chose one of two popular fitness programs, Pilates or Tae Bo, and attended it 3 times a week for 12 weeks. At the beginning and end of the study, body composition analysis and venous blood sampling were performed. The levels of superoxide anion radical, hydrogen peroxide, nitric oxide and lipid peroxidation were measured in plasma, and the levels of reduced glutathione and the activity of superoxide dismutase and catalase were measured in erythrocytes. Only the Tae Bo program induced changes (positive) in body composition, whereas both exercise programs induced slight oxidative stress in exercisers. In the Tae Bo group, the levels of hydrogen peroxide were significantly increased, whereas the levels of reduced glutathione were decreased after three months of training. In the Pilates group, hydrogen peroxide and catalase activity were increased, and nitrites decreased. However, at the end of the study, those two groups had no significantly different values for any pro/antioxidant compared with the subjects who served as controls. This finding suggests that moderate physical activity, such as recreational fitness programs, may induce the increased production of reactive oxygen species but do not lead to a serious disturbance of the redox homeostasis of exercisers.

Keywords: oxidative stress, redox balance, fitness, tae bo, pilates, women

\section{SAŽETAK}

Cilj ove studije je da ispita efekte dva programa vežbanja sa razlicitim metaboličkim zahtevima na redoks status žena koje su inicijalno bile fizički neaktivne. Žene starosti $25 \pm 5$ godina samostalno su odabrale jedan od dva ponudena fitnes programa, Pilates ili Tae bo, i pohadale ga 3 puta nedeljno tokom 12 nedelja. Na početku, $i$ na kraju studije, ispitanicama je procenjen telesni sastav i uzeti uzorci venske krvi. Nivoi superoksid anjon radikala, vodonik peroksida, azot monoksida i lipidne peroksidacije mereni su u plazmi, dok su nivoi redukovanog glutationa, $i$ aktivnost superoksid dismutaze $i$ katalaze mereni u eritrocitima. Samo Tae bo program je doveo do pozitivnih promena telesne kompozicije, dok su oba programa vežbanja dovela do narušavanja redoks homeostaze ispitanica. U Tae bo grupi nivoi vodonik peroksida su bili povećani, a nivoi redukovanog glutationa sniženi nakon 3 meseca treninga. U Pilates grupi, nivoi vodonik peroksida i aktivnost katalaze su bili povećani, a nivoi nitrita smanjeni. Ipak, na kraju studije nije bilo značajnih razlika u nivoima pro-antioksidanata izmedu ove dve grupe vežbačica i osoba koje su činile kontrolnu grupu. Ovi rezultati upućuju na zaključak da umerena fizička aktivnost, kao rekreacioni fitnes programi, može dovesti do povećane produkcije reaktivnih kiseoničnih vrsta, ali ne dovodi do ozbiljnog narušavanja redoks homeostaze vežbača.

Ključne reči: oksidativni stres, redoks ravnoteža, fitnes, tae bo, pilates, žene

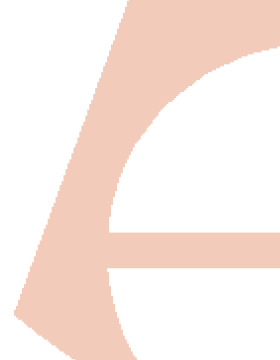

ADS - antioxidative defense system;

CAT - catalase;

GSH - reduced glutathione;

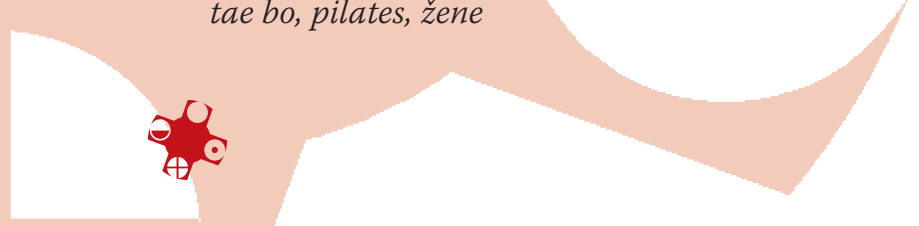

ABBREVIATIONS

RBCs - red blood cells;

RONS - reactive oxygen and nitrogen species;

SOD - superoxide dismutase;

TBARS - thiobarbituric acid reactive substances 


\section{INTRODUCTION}

Hypokinesia represents one of the major risk factors for numerous physical disorders, including cardiovascular diseases, obesity, diabetes, and osteoporosis (1). Recreational physical activities, such as different fitness programs, function in both the prevention and treatment of these abnormalities. Accumulating data indicate that exercise with moderate intensity has systemic and complex health-promoting effects, which undoubtedly involve the regulation of redox homeostasis and signalling (2). The relationship between exercise and oxidative stress has been intensively investigated for decades $(3,4)$; however, more data are required to address this association and its dependence on various relevant factors (5). For example, few studies have investigated the redox state of females. The reason for the disproportionate number of investigations on exercise-induced oxidative stress in male and female populations likely lies in the complexity of the examination and interpretation of the redox state of females, which occur due to hormonal differences between the sexes and their influence on results. It is believed that women are less susceptible to oxidative stress since because oestrogen is a potent antioxidant (6); however, one study showed that the phase of the menstrual cycle (i.e., estradiol concentration) exerts a minimal influence on the exercise-induced redox changes in young women (7).

In recent decades, a number of popular programmed group exercises for women have emerged, such as Pilates and Tae Bo. Those two fitness programs differ significantly in their metabolic and motoric demands. Tae Bo is highintensity aerobic training that uses different movements from martial arts, dance and aerobics that are combined in choreography with fast music. In contrast, Pilates is a specific form of training that is based on breathing and uses untypical initial positions and exercises to develop muscular strength and flexibility (8). Keeping in mind the deficiency of data on exercise-induced oxidative stress in females as well as the popularity of the above-mentioned fitness programs, the aim of our research was to assess the changes in the redox state of young, previously sedentary females after three months of programmed exercise. The secondary aim of the research was to compare the effects of two metabolically different exercise programs because different mechanisms and the quantity of reactive oxygen species production may be expected from a highly aerobically demanding and static, strength-oriented physical activity.

\section{MATERIAL AND METHODS}

\section{Subjects}

The sample consisted of 59 sedentary women ( $25 \pm 5$ years old). The control group consisted of 10 sedentary women, and there were two experimental groups: the Pilates $(n=19)$ and Tae Bo $(n=20)$ groups. The Pilates and Tae Bo groups took part in the experiment at will and were obligated to attend these programmed activities in addition to maintaining their usual everyday activities and nutrition. All participants were healthy, did not use medications or supplements before the beginning of the study, and were non-smokers. The study was performed in accordance with the Declaration of Helsinki and was approved by the ethical committee of The Faculty of Medical Sciences, University of Kragujevac.

\section{Protocol}

Venous blood samples were taken from all participants before the beginning of the study and 3 months later. The characteristics of the two fitness programs are presented in Table 1.

The intensity of both programs was monitored by the Polar Team ${ }^{2}$ System (Polar Electro Oy, Finland) for heart rate monitoring, which was worn by every second exerciser. Warming up in Pilates and Tae Bo consisted of exercises that included large muscle groups and lasted approximately 10 minutes. The main part lasted 45 minutes and consisted of specific exercises depending on the program (Pilates or Tae Bo). Relaxing and stretching included exercises that provided body cool down and relaxation and lasted approximately 5 minutes.

Body composition was measured using the Tanita $B C$ 418 apparatus for bioelectrical impedance analysis.

Table 1. Characteristics of Pilates and Tae Bo programs.

\begin{tabular}{|l|l|l|}
\hline Characteristic & Pilates & Tae Bo \\
\hline Duration of class & 60 minutes & 60 minutes \\
\hline Duration of program & 3 months & 3 months \\
\hline Number of classes per week & 3 classes per week & 3 classes per week \\
\hline Intensity & $50-65 \%$ HRmax & $60-85 \%$ HRax \\
\hline $\begin{array}{l}\text { Structure of class } \\
\text { 2) Warm up } \begin{array}{l}\text { Main portionRelaxation } \\
\text { (breathing exercises) }\end{array}\end{array}$ & $\begin{array}{l}\text { 2) Main portionRelaxation and } \\
\text { stretching }\end{array}$ \\
\hline $\begin{array}{l}\text { Musical tempo of main } \\
\text { portion of class }\end{array}$ & $100-110$ bpm & $130-150$ bpm \\
\hline Equipment & Resistance bands & Weights \\
\hline
\end{tabular}




\section{Biochemical assays}

Blood samples were taken from an antecubital vein into a Vacutainer test tube containing sodium citrate anticoagulant. Blood samples were analyzed immediately. Blood was centrifuged to separate plasma and red blood cells (RBCs). Biochemical parameters were measured spectrophotometrically.

\section{Superoxide anion radical determination}

The level of superoxide anion radical $\left(\mathrm{O}_{2}{ }^{-}\right)$was measured using nitro blue tetrazolium reaction in TRIS-buffer combined with plasma samples and read at $530 \mathrm{~nm}(9)$. The levels of $\mathrm{O}_{2}{ }^{-}$are presented in $\mathrm{nmol} / \mathrm{ml}$ of plasma.

\section{Hydrogen peroxide determination}

The protocol for measuring hydrogen peroxide $\left(\mathrm{H}_{2} \mathrm{O}_{2}\right)$ is based on the oxidation of phenol red in the presence of horseradish peroxidase (10). A $200 \mu$ l sample with 800 $\mu \mathrm{l}$ phenol red solution) and $10 \mu \mathrm{l}$ horseradish peroxidase were combined $(1: 20)$. The level of $\mathrm{H}_{2} \mathrm{O}_{2}$ in plasma was measured at $610 \mathrm{~nm}$. The levels of $\mathrm{H}_{2} \mathrm{O}_{2}$ are presented in $\mathrm{nmol} / \mathrm{ml}$ of plasma.

\section{Nitric oxide determination}

Nitric oxide (NO) decomposes rapidly to form stable metabolite nitrite/nitrate products. Nitrite $\left(\mathrm{NO}_{2}^{-}\right)$was determined as an index of nitric oxide production with Griess reagent (11). Approximately $0.1 \mathrm{ml} 3 \mathrm{~N}$ perchloride acid, $0.4 \mathrm{ml} 20 \mathrm{mM}$ ethylenediaminetetraacetic acid and $0.2 \mathrm{ml}$ plasma were put on ice for $15 \mathrm{~min}$ and were then centrifuged for $15 \mathrm{~min}$ at $6000 \mathrm{rpm}$. After pouring off the supernatant, $220 \mu \mathrm{K}_{2} \mathrm{CO}_{3}$ was added. Nitrites were measured at $550 \mathrm{~nm}$. Distilled water was used as a blank probe. The levels of $\mathrm{NO}_{2}{ }^{-}$are presented in $\mathrm{nmol} / \mathrm{ml}$ of plasma.

\section{Index of lipid peroxidation}

(thiobarbituric acid reactive substances, TBARS)

The degree of lipid peroxidation in plasma was estimated by measuring the thiobarbituric acid reactive substances (TBARS) using $1 \%$ thiobarbituric acid in $0.05 \mathrm{NaOH}$, whch were incubated with plasma at $100{ }^{\circ} \mathrm{C}$ for $15 \mathrm{~min}$ and read at $530 \mathrm{~nm}$. Distilled water was used as a blank probe. Thiobarbituric acid extract was obtained by combining 0.8 $\mathrm{ml}$ plasma and $0.4 \mathrm{ml}$ trichloroacetic acid; the samples were then put on ice for 10 minutes and centrifuged for $15 \mathrm{~min}$ at $6000 \mathrm{rpm}$. This method was described previously (12). The levels of TBARS are presented in $\mu \mathrm{mol} / \mathrm{ml}$ of plasma.

\section{Determination of antioxidant enzymes}

Isolated RBCs were washed three times with 3 volumes of ice-cold $0.9 \mathrm{mmol} / \mathrm{l} \mathrm{NaCl}$ and hemolysates containing approximately $50 \mathrm{~g} \mathrm{Hb} / 1$ (prepared according to McCord and Fridovich (13)) were used for the determination of catalase (CAT) activity. CAT activity was determined according to Beutler (14). Lysates were diluted with distilled water $(1: 7 \mathrm{v} / \mathrm{v})$ and treated with chloroform-ethanol $(0.6: 1 \mathrm{v} / \mathrm{v})$ to remove haemoglobin
(15). Then, $50 \mu \mathrm{l}$ catalase buffer, $100 \mu \mathrm{l}$ sample and $1 \mathrm{ml} 10 \mathrm{mM}$ $\mathrm{H}_{2} \mathrm{O}_{2}$ were added to the samples. Detection was performed at $360 \mathrm{~nm}$. Distilled water was used as a blank probe. Superoxide dismutase (SOD) activity was determined using the epinephrine method of Misra and Fridovich (16). Approximately $100 \mu \mathrm{l}$ lysate and $1 \mathrm{ml}$ carbonate buffer were mixed, and $100 \mu \mathrm{l}$ of epinephrine was added. Detection was performed at $470 \mathrm{~nm}$. The activities of SOD and CAT in red blood cells (RBCs) are presented in units per gram of haemoglobin $\mathrm{x} 10^{3}\left(\mathrm{U} / \mathrm{g} \mathrm{Hb} \times 10^{3}\right)$

\section{Determination of glutathione}

The level of reduced glutathione (GSH) was determined based on GSH oxidation with 5.5- dithio-bis-6.2-nitrobenzoic acid using the Beutler method (17); the concentration is expressed as nanomoles per millilitre of RBCs.

\section{Statistics}

The distribution of the data was checked with the Shapiro-Wilk test, and depending on its result, the appropriate parametric or nonparametric test was used. The differences between the values of means from two related samples (before and after the exercise period) were assessed by a paired t-test or Wilcoxon's test. The difference among three unrelated samples (between groups on initial and on final examination) was assessed by ANOVA or the Kruskal Wallis test, followed by the T test or Mann-Whitney U test. The alpha level for significance was set to $\mathrm{P}<0.05$.

Table 2. Anthropometric characteristics of the investigated group $\left({ }^{*} \mathrm{P}<0.05\right.$ when compared to the initial value).

\begin{tabular}{|c|c|c|}
\hline Characteristic & $\begin{array}{l}\text { Beginning of the } \\
\text { study }(\mathrm{X} \pm \mathrm{SD})\end{array}$ & $\begin{array}{l}\text { End of the study } \\
\qquad(\mathrm{X} \pm \mathrm{SD})\end{array}$ \\
\hline \multicolumn{3}{|c|}{ Height $(\mathrm{cm})$} \\
\hline Controls & \multicolumn{2}{|c|}{$171.50 \pm 4.08$} \\
\hline Pilates & \multicolumn{2}{|c|}{$169.15 \pm 6.36$} \\
\hline Tae Bo & \multicolumn{2}{|c|}{$168.70 \pm 6.20$} \\
\hline \multicolumn{3}{|c|}{ Weight (kg) } \\
\hline Controls & $61.85 \pm 7.29$ & $62.16 \pm 7.84$ \\
\hline Pilates & $63.14 \pm 7.93$ & $62.49 \pm 6.98$ \\
\hline Tae Bo & $67.35 \pm 12.80$ & $65.23 \pm 12.04^{*}$ \\
\hline \multicolumn{3}{|c|}{ Body mass index $\left(\mathrm{kg} / \mathrm{m}^{2}\right)$} \\
\hline Controls & $21.36 \pm 2.21$ & $21.47 \pm 2.30$ \\
\hline Pilates & $22.17 \pm 3.28$ & $21.89 \pm 3.03$ \\
\hline Tae Bo & $23.64 \pm 4.04$ & $23.03 \pm 3.79 *$ \\
\hline \multicolumn{3}{|c|}{ Fat (\%) } \\
\hline Controls & $19.91 \pm 5.11$ & $20.20 \pm 5.35^{*}$ \\
\hline Pilates & $21.69 \pm 7.59$ & $21.30 \pm 6.80$ \\
\hline Tae Bo & $25.23 \pm 9.40$ & $24.02 \pm 8.88^{*}$ \\
\hline \multicolumn{3}{|c|}{ Muscle (\%) } \\
\hline Controls & $13.76 \pm 0.97$ & $13.84 \pm 1.07$ \\
\hline Pilates & $13.71 \pm 1.37$ & $13.67 \pm 1.18$ \\
\hline Tae Bo & $12.98 \pm 1.62$ & $13.19 \pm 1.55^{*}$ \\
\hline
\end{tabular}




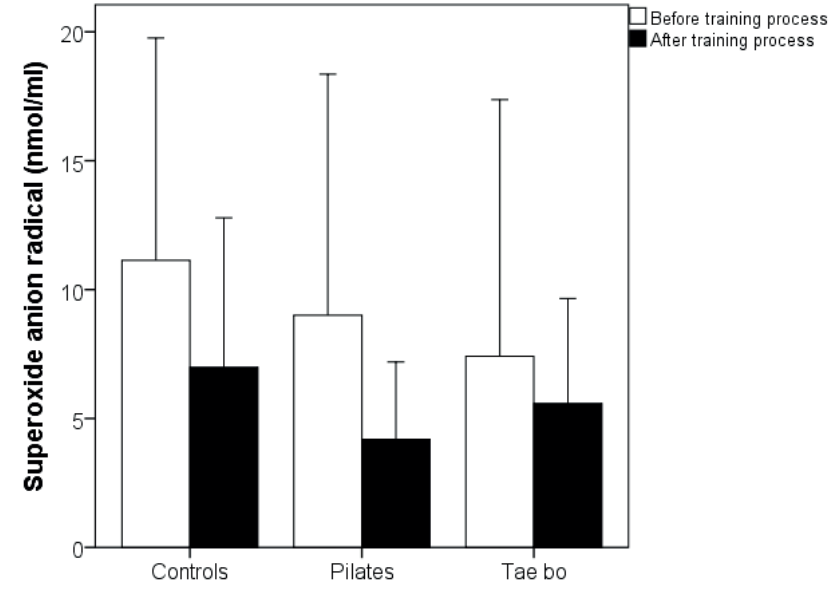

Figure 1. Levels of superoxide anion radical $(\mathrm{X} \pm \mathrm{SD})$ in the investigated groups before and after the training period.

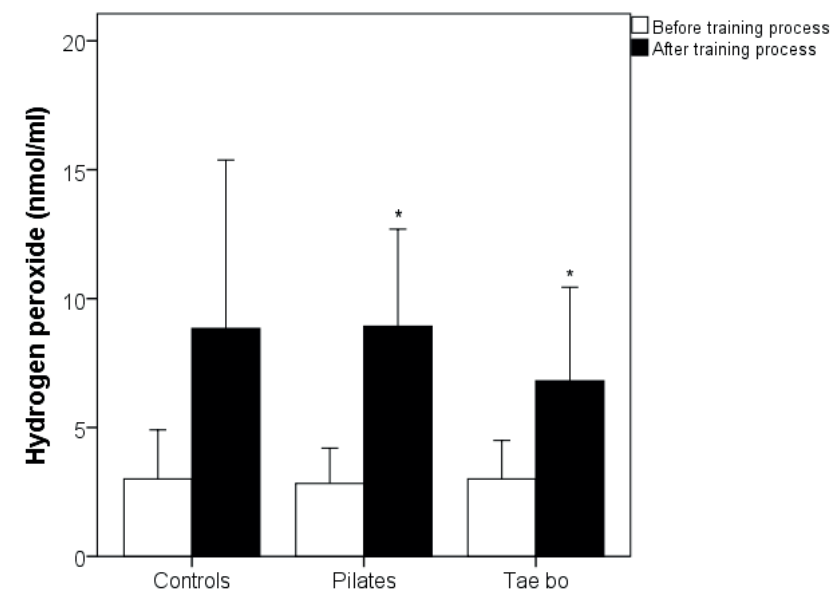

Figure 2. Levels of hydrogen peroxide $(\mathrm{X} \pm \mathrm{SD})$ in the investigated groups before and after the training period ( ${ }^{*} \mathrm{P}<0.05$ compared with the beginning of the study).

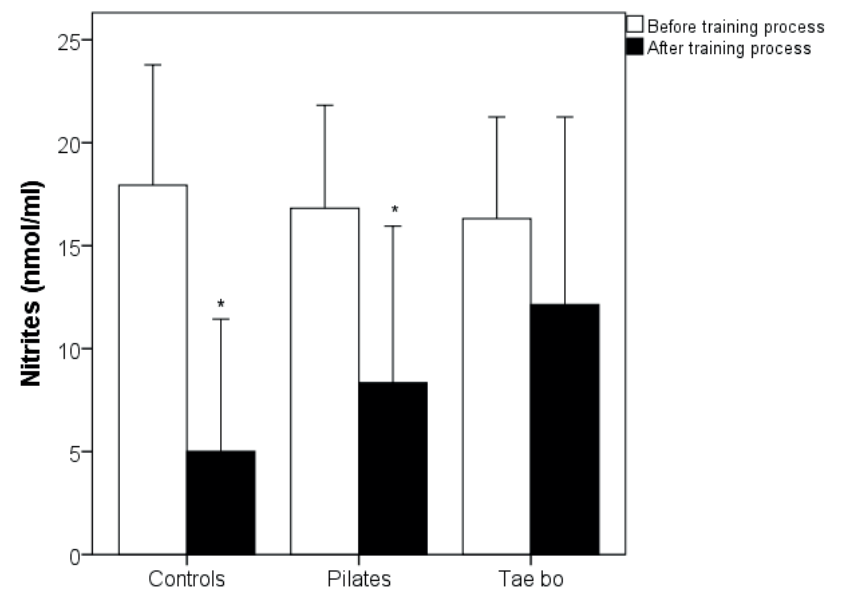

Figure 3. Levels of nitrites $(\mathrm{X} \pm \mathrm{SD})$ in the investigated groups before and after the training period $(* \mathrm{P}<0.05$ compared with the beginning of the study).

\section{RESULTS}

The anthropometric characteristics of the investigated groups at the beginning and at the end of the study are presented in Table 2. After three months of training, all parameters of body composition changed significantly in subjects who practiced Tae Bo (body weight: $\mathrm{P}=0.002$, \% fat: $\mathrm{P}=0.005$, \% muscle: $\mathrm{P}=0.008$, $\mathrm{BMI}: \mathrm{P}=0.002)$, and the body fat increased in the control group $(\mathrm{P}=0.038)$. However, there was no significant difference between groups in the investigated anthropometric parameters at either the beginning or the end of the study.

Changes in levels of pro/antioxidants in plasma and red blood cells of subjects are presented in Figures 1 to 7 . The levels of $\mathrm{NO}_{2}^{-}$were significantly lower in the Control $(\mathrm{P}=0.043)$ and Pilates $(\mathrm{P}=0.007)$ groups compared with the levels measured at the beginning of the study. The Pilates group also had higher levels of $\mathrm{H}_{2} \mathrm{O}_{2}(\mathrm{P}=0.001)$ and CAT activity $(\mathrm{P}=0.011)$ at the end of the study. In the Tae Bo group, $\mathrm{H}_{2} \mathrm{O}_{2}$ increased $(\mathrm{P}=0.002)$, but $\mathrm{GSH}$ decreased $(\mathrm{P}=0.006)$ after three months of training.

The differences between groups in the levels of investigated redox parameters are also presented in Figures 1 to 7. At the beginning of the study, subjects from the Control group had significantly lower SOD activity compared with both the Tae Bo $(\mathrm{P}=0.040)$ and Pilates groups $(\mathrm{P}=0.037)$. At the end of the study, the groups did not significantly differ in any redox parameter.

\section{DISCUSSION}

The aim of the present study was to assess the effects of two metabolically different exercise programs on the redox state of women who were physically inactive before the beginning of the study. For this purpose, participants chose one of two popular fitness programs, Pilates or Tae Bo, and attended it three times a week for 12 weeks. At the beginning and end of the study, body composition analysis and blood sampling were performed. Only the Tae Bo program induced (positive) changes in body composition, although both exercise programs disturbed the redox homeostasis of subjects.

There is a common acceptance that Pilates and other forms of low-intensity exercises, when they are performed slowly and with proper breathing, will do far more to improve health status than will a vigorous cardiovascular or strength workout (18). Those types of exercise may be classified as parasympathetic exercise: they do not raise the heart rate and breathing rate significantly, but they significantly reduce stress levels (18). In contrast, intensive aerobic exercise, such as Tae Bo, is characterized by increased oxygen consumption and a possible disturbance of intracellular pro/antioxidant homeostasis. In general, the body has adequate antioxidant reserves to cope with the production of reactive oxygen species (ROS) under physiological conditions and perhaps during low- to moderate- 


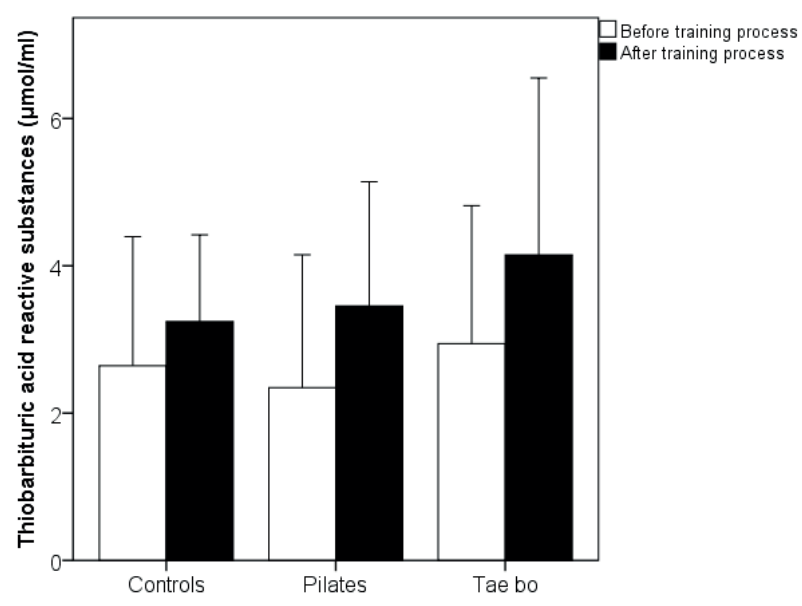

Figure 4. Levels of thiobarbituric acid reactive substances $(X \pm S D)$ in the investigated groups before and after the training period.

intensity exercise, but when ROS production is excessive, as occurs during intensive physical efforts, an imbalance between prooxidants and antioxidants in favour of the prooxidants may occur and may lead to a disruption of redox signalling and control and/or molecular damage (19). The effect of exercise on the redox state of an individual depends on many factors, such as the type of training, training load, and individual reaction of an athlete depending on age, gender, and the coexisting factors of risk and physical condition (20). In our study, subjects from both the Pilates and Tae Bo groups had increased levels of $\mathrm{H}_{2} \mathrm{O}_{2}$ compared with the levels measured before engagement in exercise training, although the levels of this prooxidant all other measured redox parameters were not significantly different among the investigated groups (Control, Pilates and Tae Bo) at the end of the study. In addition to the increase in $\mathrm{H}_{2} \mathrm{O}_{2}$ levels, at the end of the study, the Pilates group had increased CAT activity and decreased levels of $\mathrm{NO}_{2}^{-}$(as a marker of $\mathrm{NO}$ ) in blood, whereas the Tae Bo group experienced a decrease in the levels of GSH. In the Control group, a decrease in the $\mathrm{NO}_{2}$ - levels was observed at the end of the study. Those results are consistent with the results of the only similar previously published study (18). In that study, Radovanovic and colleagues reported increased values of the activity of malondialdehyde, protein carbonyls and total sulphydryls in both Pilates- and Tae Bo-trained subjects, but there were no significant differences between the groups (18). After 12 weeks of training, the CAT activity increased in both groups, but the increase was significant only in the Pilates group, whereas Tae Bo subjects had significantly increased total serum antioxidant activity (18).

The results that we obtained suggest that both of the exercise programs induced changes in the redox state of exercisers in the direction of oxidative stress. At the end of the study, the Tae Bo subjects had significantly higher levels of $\mathrm{H}_{2} \mathrm{O}_{2}$ and lower levels of $\mathrm{GSH}$, which is an element of the endogenous antioxidant system that is directly involved in $\mathrm{H}_{2} \mathrm{O}_{2}$ elimination. In contrast, in the Pilates group, the

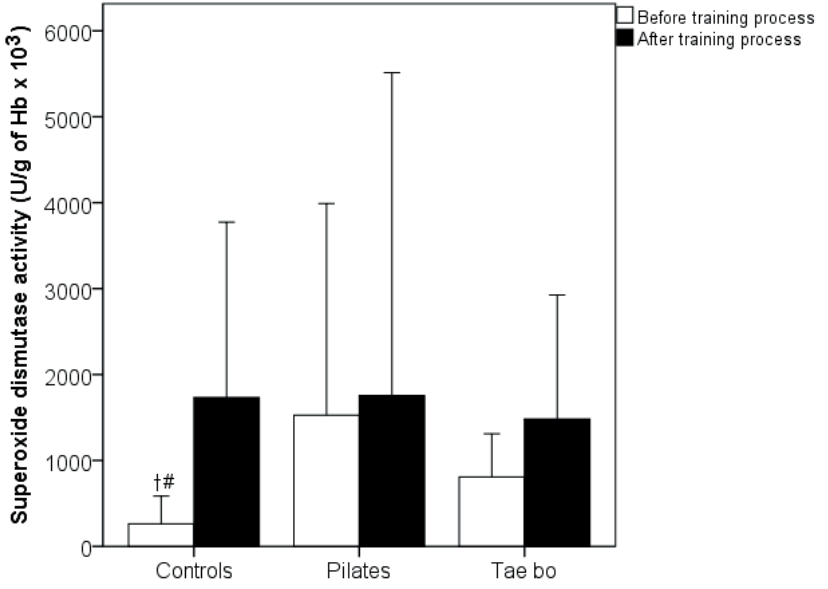

Figure 5. Superoxide dismutase activity $(X \pm S D)$ in the investigated groups before and after the training period $(+\mathrm{P}<0.05$ compared with the Pilates group at the beginning of the study; $\# \mathrm{P}<0.05$ compared with the Tae Bo group at the beginning of the study).

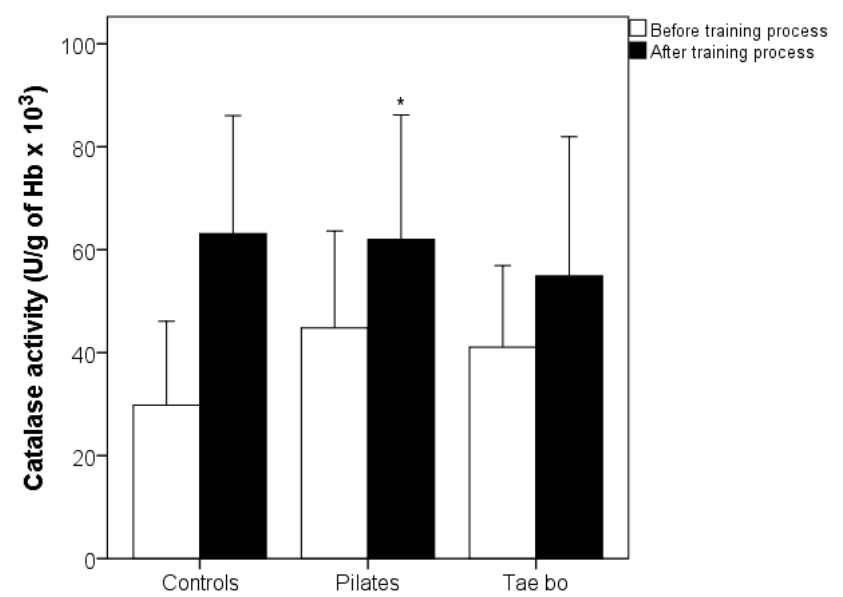

Figure 6. Catalase activity $(\mathrm{X} \pm \mathrm{SD})$ in the investigated groups before and after the training period ( $\left({ }^{*} \mathrm{P}<0.05\right.$ compared with the beginning of the study).

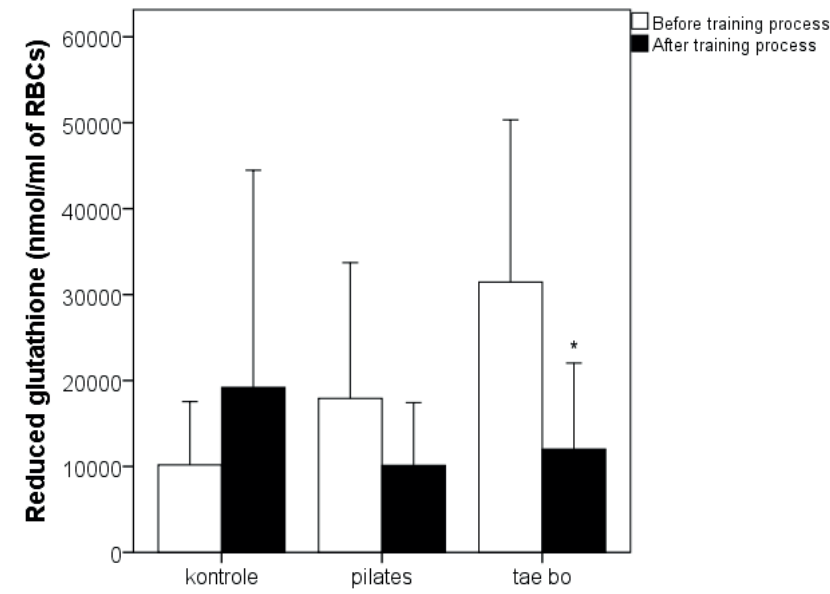

Figure 7. Levels of reduced glutathione $(\mathrm{X} \pm \mathrm{SD})$ in the investigated groups before and after the training period ( $\mathrm{P}<0.05$ compared with the beginning of the study). 
increased $\mathrm{H}_{2} \mathrm{O}_{2}$ levels were followed by increased CAT activity, with no significant change in the levels of GSH. GSH both directly and indirectly (as a cofactor for glutathione peroxidase - GPx) eliminates free radicals (21). CAT and GPx are both engaged in $\mathrm{H}_{2} \mathrm{O}_{2}$ elimination, but their affinity for it is different and dose-dependent. The affinity of GPx for $\mathrm{H}_{2} \mathrm{O}_{2}$ is higher at low $\mathrm{H}_{2} \mathrm{O}_{2}$ levels, whereas CAT affinity increases with an increase in the $\mathrm{H}_{2} \mathrm{O}_{2}$ levels. Although the difference was not found to be statistically significant, the Pilates group had higher levels of $\mathrm{H}_{2} \mathrm{O}_{2}$ than did the Tae Bo group, which increased the CAT activation to higher (significant) levels. Interestingly, no group had increased levels of lipid peroxidation (measured through TBARS), which would be expected, especially in the Tae Bo group, whose levels of GSH were exhausted. It was previously shown that GSH blood levels are a determinant of plasma TBARS at rest (22). Subjects with a favourable blood glutathione redox status at rest maintain a more favourable redox status in response to exercise-induced oxidative stress, and vice versa (22). Furthermore, the levels of $\mathrm{NO}_{2}{ }^{-}$were also found to be decreased in the Control and Pilates groups, though that was not the case in subjects who practiced Tae Bo. The absence of change in the Tae Bo group may be explained by the effect of increased shear stress on endothelium, characteristic for high-intensity aerobic exercise. Numerous previous studies have shown that regular endurance activity increases the bioavailibity of $\mathrm{NO}$ (23-25) and that physically active people have greater basal NO production compared with a sedentary population $(26,27)$. Finally, the observed differences between the groups in the levels of SOD at the beginning of the study may be explained by the more active lifestyle of subjects who chose to be engaged in training, and they likely do not represent the control group. The absence of significant changes in SOD activity due to the three-month training program is surprising because the majority of previously published studies showed that it is the enzyme that is most susceptible to change due to acute or chronic exercise (28).

\section{CONCLUSION}

Although both exercise programs induced an increase in the production of reactive oxygen species, the fact that exercisers did not have significantly different values for any pro/antioxidant relative to controls suggests that moderate physical activity, such as participation in recreational fitness programs, does not lead to a serious disturbance of the redox homeostasis of exercisers. Furthermore, as we previously reported (29), both Pilates and Tae Bo induced significant improvements of the motoric status of women, especially balance and leg and abdominal strength. However, because only Tae Bo induced significant changes in the body composition of exercisers, this high-intensity aerobic activity should be the activity of choice for those who wish to lose and control their weight.

\section{ACKNOWLEDGEMENTS}

This work was supported by junior project 9/2011 by the faculty of medical sciences, University of Kragujevac, Serbia.

\section{REFERENCES}

1. Hardman AE, Stensel DJ. Physical activity and health: the evidence explained. London: Routledge, Taylor and Francis Group, 2009.

2. Radak Z, Zhao Z, Koltai E, Ohno H, Atalay M. Oxygen consumption and usage during physical exercise: the balance between oxidative stress and ROS-dependent adaptive signaling. Antioxid Redox Signal 2013; 18(10): 1208-46.

3. Fisher-Wellman K, Bloomer RJ. Acute exercise and oxidative stress: a 30 year history. Dyn Med 2009; 8:1-25.

4. Finaud J, Lac G, Filaire E. Oxidative stress: relationship with exercise and training. Sports Med 2006; 36(4): 327-58.

5. Finkler M, Lichtenberg D, Pinchuk I. The relationship between oxidative stress and exercise. J Basic Clin Physiol Pharmacol 2013; 17: 1-11.

6. Joo MH, Maehata E, Adachi T, Ishida A, Murai F, Mesa$\mathrm{ki}$ N. The relationship between exercise-induced oxidative stress and the menstrual cycle. Eur J Appl Physiol 2004; 93(1-2): 82-6.

7. Chung SC, Goldfarb AH, Jamurtas AZ, Hegde SS, Lee J. Effect of exercise during the follicular and luteal phases on indices of oxidative stress in healthy women. Med Sci Sports Exerc 1999; 31(3): 409-13.

8. Amorim TP, Sousa FM, Rodrigues dos Santos JA. Influence of Pilates training on muscular strength and flexibility in dancers. Motriz: Rev Educ Fis 2011; 17(4): 660-6.

9. Auclair C, Voisin E. Nitroblue tetrazolium reduction. In: Greenwald RA, ed. Handbook of methods for oxygen radical research. Boka Raton, FL: CRC Press, 1985: 123-132.

10. Pick E, Keisari Y. A simple colorimetric method for the measurement of hydrogen peroxide produced by cells in culture. J Immunol Methods 1980; 38(1-2): 161-70.

11. Green LC, Wagner DA, Glogowski J, Skipper PI, Wishnok JS, Tannenbaum SR. Analysis of nitrate, nitrite and $\left[{ }^{15} \mathrm{~N}\right]$ nitrate in biological fluids. Anal Biochem 1982; 126(1): 131-8.

12. Ohkawa H, Ohishi N, Yagi K. Assay for lipid peroxides in animal tissues by thiobarbituric acid reaction. Anal Biochem 1979; 95(2): 351-8.

13. McCord JM, Fridovich I. The utility of superoxide dismutase in studying free radical reactions. Radicals generated by the interaction of sulfite, dimethyl sulfoxide, and oxygen. J Biol Chem 1969; 244(22): 6056-63.

14. Beutler E. Catalase. In: Beutler E, ed. Red cell metabolism, a manual of biochemical methods. New York: Grune and Stratton, 1982: 105-6. 
15. Tsuchihashi M. Zur Kernntnis der blutkatalase. Biochem Z 1923; 140: 65-72.

16. Misra HP, Fridovich I. The role of superoxide-anion in the autooxidation of epinephrine and a simple assay for superoxide dismutase. J Biol Chem 1972; 247(10): 3170-5.

17. Beutler E. Reduced glutathione (GSH). In: Beutler E, ed. Red cell metabolism, a manual of biochemical methods. New York: Grune and Stratton, 1975: 112-4.

18. Radovanovic D, Jakovljevic V, Cvetkovic T, Ignjatovic A, Veselinovic N, Dondur S. Effects of different exercise program on blood markers of oxidative stress in young women. Fiziologia 2008; 18(3): 16-8.

19. Powers SK, Nelson BW, Hudson MB. Exercise-induced oxidative stress in humans: Cause and consequences. Free Rad Biol Med 2011; 51(5): 942-50.

20. Vollaard NB, Shearman JP, Cooper CE. Exercise-induced oxidative stress:myths, realities and physiological relevance. Sports Med 2005; 35(12): 1045 - 62.

21. Masella R, Di Benedetto R, Vari R, Filesi C, Giovannini C. Novel mechanisms of natural antioxidants compounds in biological systems. Involvement of glutathione and glutathione related enzymes. J Nutrit Biochem 2005; 16: 577-86.

22. Laaksonen DE, Atalay M, Niskanen L, Uusitupa M, Hänninen O, Sen CK. Blood glutathione homeostasis as a determinant of resting and exercise-induced oxidative stress in young men. Redox Rep 1999: 4(1-2): 53-9.
23. Cubrilo D, Djordjevic D, Zivkovic V, et al. Oxidative stress and nitrite dynamics under maximal load in elite athletes: relation to sport type. Mol Cell Biochem 2011; 355: 273-9.

24. Maeda S, Miyauchi T, Kakiyama T, et al. Effects of exercise training of 8 weeks and detraining on plasma levels of endothelium-derived factors, endothelin-1 and nitric oxide in healthy young humans. Life Sci 2001; 69(9): 1005-16.

25. Maiorana A, O’Driscoll G, Taylor R, Green D. Exercise and the nitric oxide vasodilator system. Sports Med 2003; 33(14): 1013-35.

26. Poveda JJ, Riestra A, Salas E, et al.Contribution of nitric oxide to exercise-induced changes in healthy volunteers: effects of acute exercise and long-term physical training. Eur J Clin Invest 1997; 27(11): 967-71.

27. Green DJ, Maiorana A, O’Driscoll G, Taylor R. Effect of exercise training on endothelium-derived nitric oxide function in humans. J Physiol 2004; 561: 1-25.

28. Djordjevic D, Cubrilo D, Zivkovic V, Barudzic N, Vuletic M, Jakovljevic V. Pre-exercise superoxide dismutase activity affects the pro/antioxidant response to acute exercise. Serbian J Exp Clin Res 2010; 11(4): 147-5

29. Stojanovic Tosic J, Djordjevic D. Differences in motoric abilities of women attending different recreational exercise programs. $3^{\text {rd }}$ International Scientific Conference „Exercise and quality of life“, Novi Sad, Serbia, April 12-13, 2013. Proceedings: 401-406. 